\title{
KAJIAN KARAKTERISTIK DAN POLA PENGOBATAN PASIEN INFEKSI MENULAR SEKSUAL DI RSUD AW SJAHRANIE SAMARINDA
}

\author{
Yuniarti Pudji Rahayu*, Adam M. Ramadhan, Laode Rijai \\ Fakultas Farmasi Universitas Mulawarman, Samarinda, Kalimantan Timur \\ *Email: vuniartipudjirahayu06@yahoo.com
}

\begin{abstract}
ABSTRAK
Penyakit menular seksual adalah bagian dari infeksi saluran reproduksi yang disebabkan oleh bakteri, jamur, dan virus yang masuk dan berkembang biak di dalam tubuh yang ditularkan melalui hubungan seksual. Penelitian ini bertujuan untuk mengetahui karakteristik pasien, jenis-jenis penyakit infeksi menular seksual, dan pengobatan infeksi menular seksual. Metode ini dilakukan secara retrospektif dengan menggunakan hasil observasi. Hasil penelitian menunjukkan bahwa pasien infeksi menular terbanyak berjenis kelamin laki-laki yakni sebanyak 55 pasien $(50,93 \%)$, sedangkan 53 pasien $(49,07 \%)$ berjenis kelamin perempuan. Karakteristik pasien laki-laki penderita infeksi menular seksual mayoritas berusia pada masa dewasa awal, 26-35 (21,29 \%), tingkat pendidikan SLTA (41,67\%), pekerjaan sebagai karyawan swasta $(34,26 \%)$, dan status belum menikah $(27,78 \%)$. Sedangkan karakteristik pada pasien perempuan penderita PMS mayoritas berusia pada masa remaja akhir, 17-25 (22,22\%), tingkat pendidikan SLTA (21,30\%), pekerjaan sebagai IRT $(25,93 \%)$, dan status menikah $(36,11 \%)$. Jenis penyakit infeksi menular seksual dengan kasus terbanyak pada pasien laki-laki ialah Gonorrhea yakni sebanyak 24,07 \%, sedangkan pada pasien perempuan ialah Kondiloma Akuminata yakni sebanyak 24,07\%. Obat yang paling sering digunakan pada pengobatan Gonorrhea ialah Sefiksim $(38,71 \%)$, pada pengobatan Kondiloma Akuminata ialah Ciprofloxacin (28,57\%), pada pengobatan Herpes Genital ialah Asiklovir (77,80\%), pada pengobatan Candidiasis ialah Ketokonazol $(100 \%)$, pada pengobatan Sifilis ialah Doxicyclin $(66,67 \%)$, pada pengobatan Ulkus Genital ialah Ciprofloxacin (50\%), dan pada pengobatan Trichomoniasis ialah Metronidazol $(66,67 \%)$.
\end{abstract}

Kata kunci : Penyakit Menular Seksual, Karakteristik, Pola Pengobatan

\section{PENDAHULUAN}

Penyakit menular seksual adalah bagian dari infeksi saluran reproduksi yang disebabkan oleh kuman seperti jamur, virus, dan parasit yang masuk dan berkembang biak di dalam tubuh yang ditularkan melalui hubungan seksual ${ }^{4}$.

Menurut data Profil Kesehatan Provinsi Kalimantan Timur menyatakan bahwa jumlah kasus baru infeksi menular seksual di Provinsi Kalimantan Timur pada tahun 2013 tercatat sebanyak 3.204 kasus, yang terdiri dari 528 pasien laki-laki dan 2.676 pasien perempuan. Selain itu tercatat pula bahwa jumlah kasus infeksi menular seksual terbanyak yakni terjadi di Kota Samarinda. 


\section{METODE PENELITIAN}

Jenis penelitian ini merupakan penelitian deskriptif kuantitatif non eksperimental yang dilakukan secara retrospektif. Penelitian ini dilakukan dengan mengumpulkan data rekam medik pasien infeksi menular seksual (meliputi karakteristik usia, jenis kelamin, pekerjaan, tingkat pendidikan dan status keluarga serta jenis penyakit infeksi menular seksual yang diderita dan juga tindakan terapi pada pasien infeksi menular seksual) yang terdapat di instalasi rawat jalan RSUD A.W. Syahranie Samarinda Periode Januari-Desember 2015. Data yang diperoleh akan dianalisis dan disajikan secara deskriptif.

Jumlah keseluruhan populasi yakni 128 pasien dan sampel yang diambil berdasarkan kriteria inklusi terdapat 108 pasien, kriteria inklusi yang dimaksud yaitu pasien dengan diagnosa infeksi menular seksual tanpa komplikasi serta mempunyai data rekam medik yang lengkap.

\section{HASIL DAN PEMBAHASAN}

\section{Karakteristik Pasien}

\section{a. Distribusi Pasien Berdasarkan Jenis Kelamin}

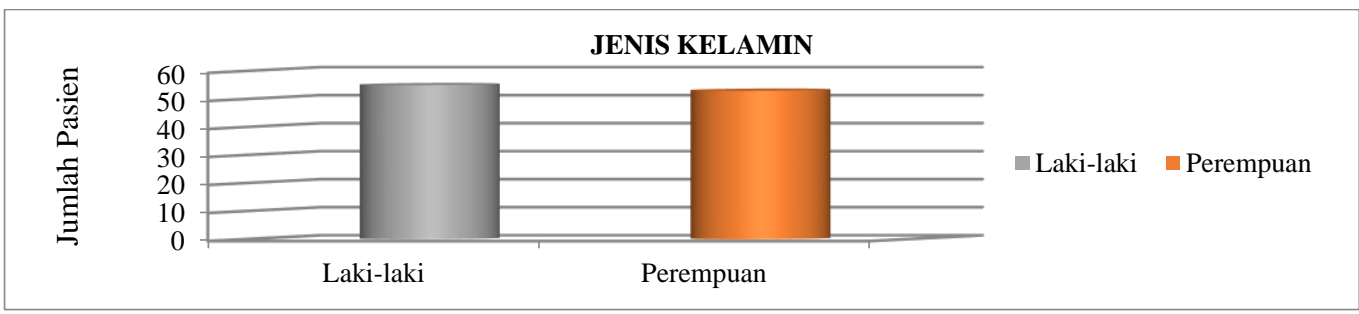

Gambar 1. Diagram Distribusi Pasien Berdasarkan Jenis Kelamin.

Hasil penelitian menunjukkan bahwa sebanyak 55 pasien (50,93\%) berjenis kelamin laki-laki, sedangkan 53 pasien (49,07\%) berjenis kelamin perempuan. Pada penelitian ini terlihat bahwa kejadian infeksi menular seksual lebih banyak dialami oleh laki-laki dibandingkan perempuan. Hal tersebut dikarenakan laki-laki yang terinfeksi selalu menunjukkan gejala atau bersifat simptomatis sehingga akan segera memeriksakan diri untuk memperoleh pengobatan. Sementara $80 \%$ wanita yang terinfeksi tidak mengeluhkan adanya gejala atau bersifat asimptomatis, oleh sebab itu tidak segera mencari pengobatan ${ }^{2}$. 


\section{b. Distribusi Pasien Berdasarkan Usia}

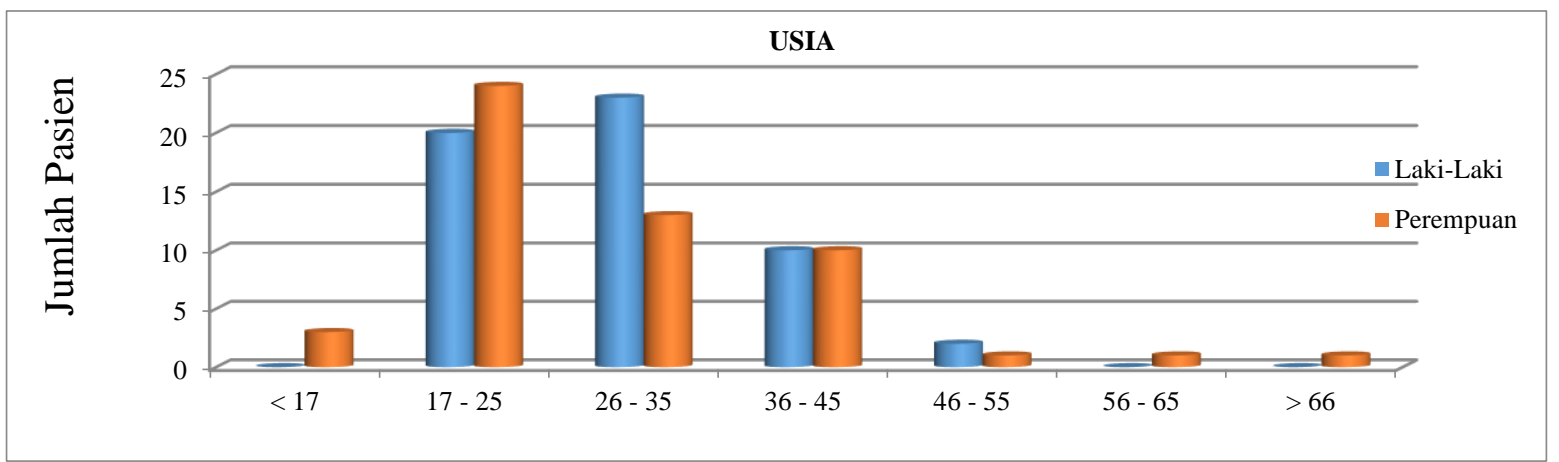

Gambar 2. Diagram Distribusi Pasien Berdasarkan Usia

Hasil penelitian menunjukkan bahwa pasien laki-laki yang mengalami infeksi menular seksual berada pada kelompok usia 26-35 tahun menunjukkan persentase terbesar yaitu $21,29 \%$ atau sebanyak 23 pasien. Sedangkan pada pasien perempuan yang mengalami infeksi menular seksual pada kelompok usia 17-25 tahun menunjukkan persentase terbesar yaitu 22,22\% atau sebanyak 24 pasien. Kelompok yang tergolong berisiko tinggi terkena infeksi menular seksual antara lain kelompok umur 20-35 tahun pada laki-laki dan 15-25 tahun pada perempuan.

Hubungan seksual pada remaja dapat meningkatkan kerentanan terhadap infeksi menular seksual. Hal ini disebabkan karena pada saat umur muda, sel-sel reproduksi masih belum matang secara sempurna. Terpajan proses ini sebelum matur dapat merusak sel-sel yang belum matang tersebut ${ }^{1}$.

\section{b. Distribusi Pasien Berdasarkan Tingkat Pendidikan}

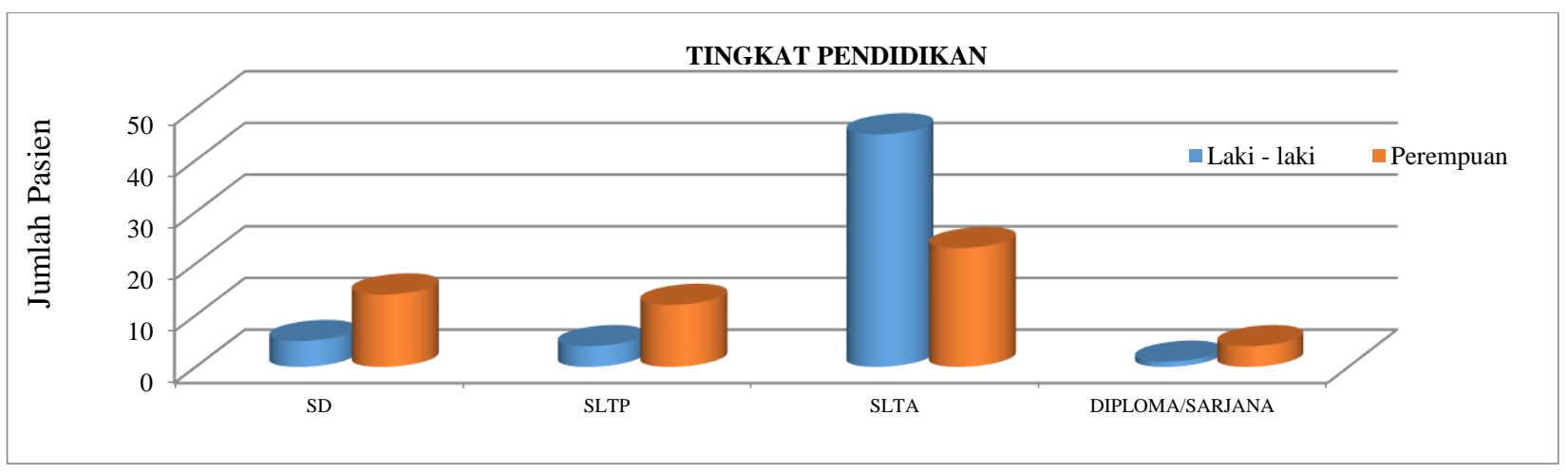

Gambar 3. Diagram Distribusi Pasien Berdasarkan Tingkat Pendidikan. 
Hasil penelitian menunjukkan bahwa pasien infeksi menular seksual, baik laki-laki maupun perempuan mayoritas memiliki tingkat pendidikan SLTA. Tingkat pendidikan pasien infeksi menular seksual tergolong pendidikan menengah. Sehingga dapat dikatakan bahwa tingkat pendidikan pasien infeksi menular seksual masih tergolong rendah.

\section{c. Distribusi Pasien Berdasarkan Jenis Kelamin}

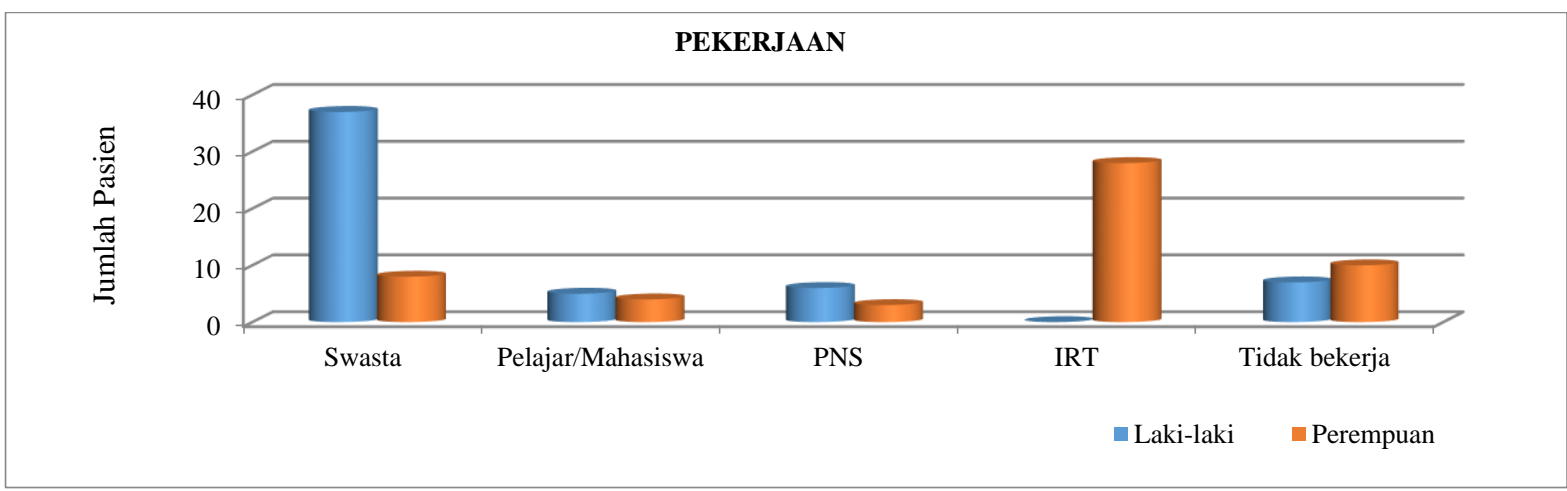

Gambar 4. Diagram Distribusi Pasien Berdasarkan Pekerjaan.

Hasil penelitian menunjukkan bahwa pada pasien laki-laki dengan pekerjaan sebagai karyawan swasta dan perempuan sebagai ibu rumah tangga lebih rentan menderita infeksi menular seksual. Infeksi menular seksual tidak hanya terjadi pada seseorang dengan status sosial kurang, akan tetapi dapat juga terjadi pada seseorang dengan status ekonomi yang baik. Dalam hal ini yang dimaksud ialah pekerjaan sebagai karyawan swasta. Hal ini disebabkan tingginya kebutuhan akan seks, jauh dari keluarga dan terjadinya kejenuhan dalam rumah tangga yang mengakibatkan seseorang melakukan hal-hal negatif seperti menggunakan jasa pekerja seks komersial. Dengan status sosial ekonomi yang baik mereka merasa mampu untuk menggunakan jasa pekerja seks komersial dan suka bergonta-ganti pasangan sehingga menyebabkan seseorang lebih rentan untuk tertular atau menularkan infeksi menular seksual. Oleh sebab itu pula ibu rumah tangga lebih rentan terkena infeksi menular seksual yang ditularkan oleh suami yang bergonta-ganti pasangan seksual atau menggunakan jasa prostitusi ${ }^{6}$.

\section{d. Distribusi Pasien Berdasarkan Status Pernikahan}

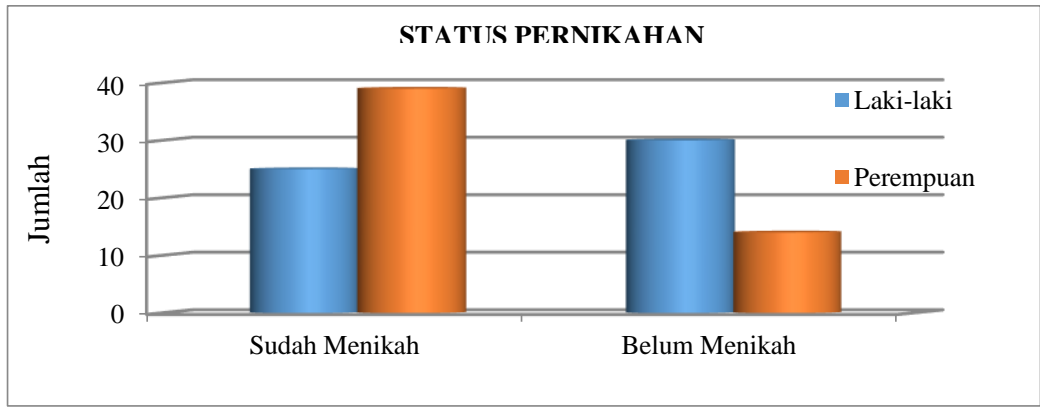

Gambar 5. Diagram Distribusi Pasien Berdasarkan Status Pernikahan. 
Hasil penelitian menunjukkan bahwa pasien infeksi menular seksual berdasarkan status pernikahan menunjukkan bahwa laki-laki yang memiliki status belum menikah dan perempuan dengan status sudah menikah lebih cenderung terkena infeksi menular seksual. Kejadian infeksi menular seksual biasanya lebih banyak terjadi pada seseorang laki-laki yang belum menikah, bercerai, atau orang yang terpisah dari keluarganya. Hal ini dikarenakan pada laki-laki yang belum menikah memiliki kebutuhan seksual yang lebih tinggi dibandingkan dengan seseorang yang sudah menikah, sehingga perilaku seks yang tidak aman dengan pasangan yang berganti-ganti berisiko tertular infeksi tersebut. Sedangkan pada perempuan lebih banyak terjadi pada status sudah menikah dikarenakan tertular oleh suami yang lebih dahulu terinfeksi penyakit menular seksual. Dapat pula disebabkan oleh suami yang berganti-ganti pasangan atau pun melakukan hubungan seksual dengan pekerja seks komersial akibat kejenuhan dalam rumah tangga sehingga menyebabkan istri rentan terhadap infeksi menular seksual. Sehingga insiden infeksi menular seksual lebih banyak pada kelompok perempuan sudah menikah karena kelompok ini memiliki faktor lebih besar untuk tertular IMS ${ }^{6}$.

\section{Jenis Penyakit Infeksi Menular Seksual}

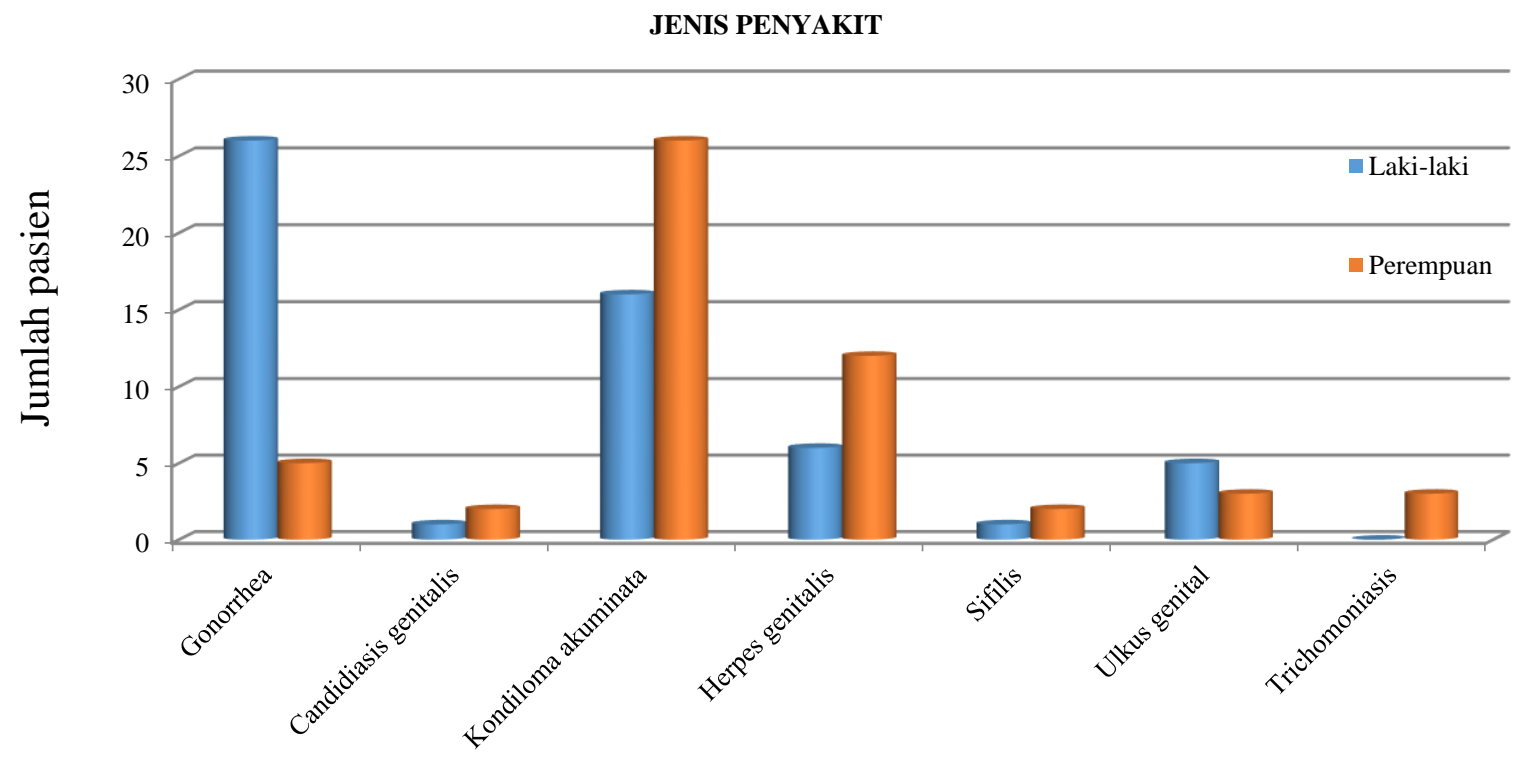

Gambar 6. Diagram Distribusi Jenis Penyakit Infeksi Menular Seksual

Hasil penelitian menunjukkan bahwa jenis penyakit yang paling banyak terjadi pada pasien laki-laki ialah gonorrhea. Sedangkan jenis penyakit yang paling banyak terjadi pada pasien perempuan ialah kondiloma akuminata. Hal tersebut dikarenakan pada laki-laki yang terinfeksi gonorrhea selalu menunjukkan adanya gejala seperti rasa nyeri pada saat kencing, keluarnya nanah kental kuning-kehijauan, ujung penis agak merah dan bengkak sehingga mereka segera mencari pengobatan ${ }^{3}$. Sedangkan jenis penyakit kondiloma akuminata paling banyak diderita oleh perempuan, hal ini dikarenakan perempuan memiliki permukaan 
mukosa yang tipis pada vulva, serviks, perineum dan di sekitar anus, dimana area tersebut sangat mudah mengalami trauma atau luka. Virus Papilloma Humanus masuk ke dalam tubuh melalui mikrolesi pada kulit, sehingga kondiloma akuminata sering timbul pada daerah yang mudah mengalami trauma pada saat melakukan hubungan seksual ${ }^{10}$.

\section{Pola Pengobatan}

\section{a. Pola Pengobatan Gonorrhea}

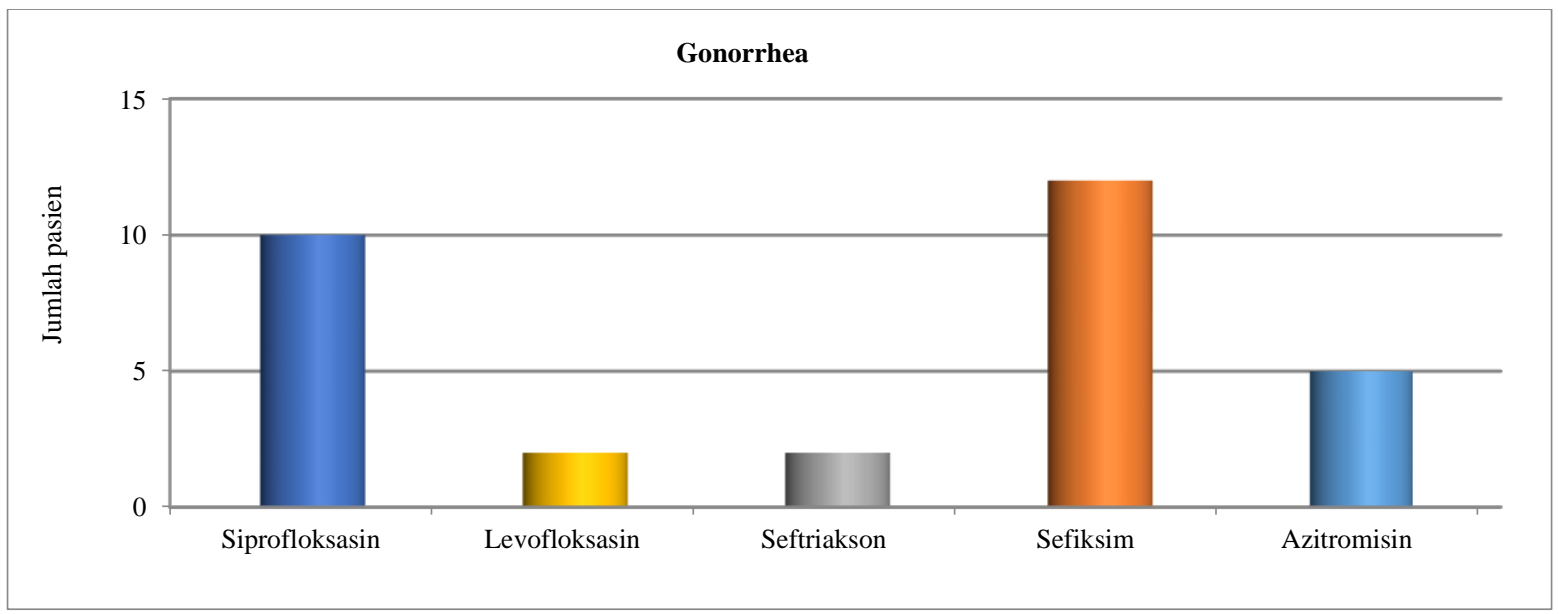

Gambar 7. Diagram Distribusi Pengobatan Pasien Gonorrhea.

Hasil penelitian menunjukkan bahwa golongan obat yang paling banyak diberikan pada pasien gonorrhea adalah golongan antibiotik sefalosporin generasi ketiga yakni sefiksim dengan persentase sebesar 38,71\%.

Sefalosporin memiliki sifat yang lebih stabil terhadap cincin $\beta$-laktamase yang diproduksi bakteri sehingga memiliki spektrum kerja yang lebih luas. Antibiotik golongan ini berperan sebagai bakterisidal, membunuh bakteri $N$. gonorrheae. Mekanisme kerja golongan sefalosporin dalam menghambat sintesis dinding sel bakteri yaitu dengan cara menghambat protein pengikat penisilin. Terapi dosis tunggal yang dianjurkan untuk gonorrhea tanpa komplikasi yaitu pemberian antibiotika sefiksim $400 \mathrm{mg}$ peroral ${ }^{2}$. 


\section{b. Pola Pengobatan Candidiasis genitalis}

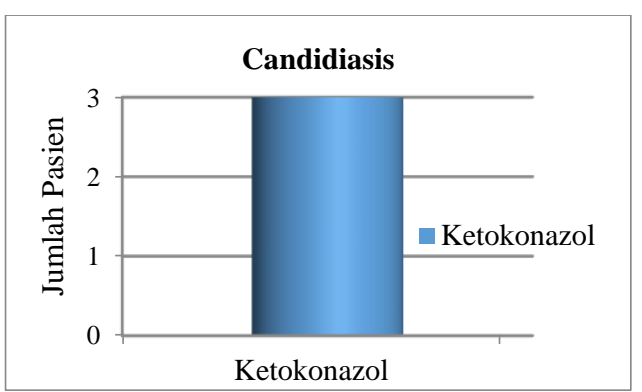

Gambar 8. Diagram Distribusi Pengobatan Pasien Candidiasis genitalis.

Hasil penelitian menunjukkan bahwa obat yang banyak digunakan pada pengobatan candidiasis genitalis adalah antijamur golongan imidazol yaitu ketokonazol dengan persentase sebesar 100\%. Terdapat 3 kasus candidiasis genitalis dan ketiganya menggunakan terapi anti jamur golongan imidazol yaitu ketokonazol.

Ketokonazol merupakan golongan azol sintetik derivat imidazol yang mempunyai aktivitas antijamur dengan spektrum luas baik sistemik maupun non sistemik, memiliki efektivitas tinggi terhadap Candida $s p$ dalam pengobatan candidiasis vaginalis. Mekanisme kerjanya melalui pengikatan enzim sitokrom P450 yang sangat diperlukan untuk sintesis ergosterol. Ketokonazol digunakan dalam pengobatan candidiasis genitalis dengan dosis 200-400 mg/hari ${ }^{8}$.

\section{c. Pola Pengobatan Kondiloma akuminata}

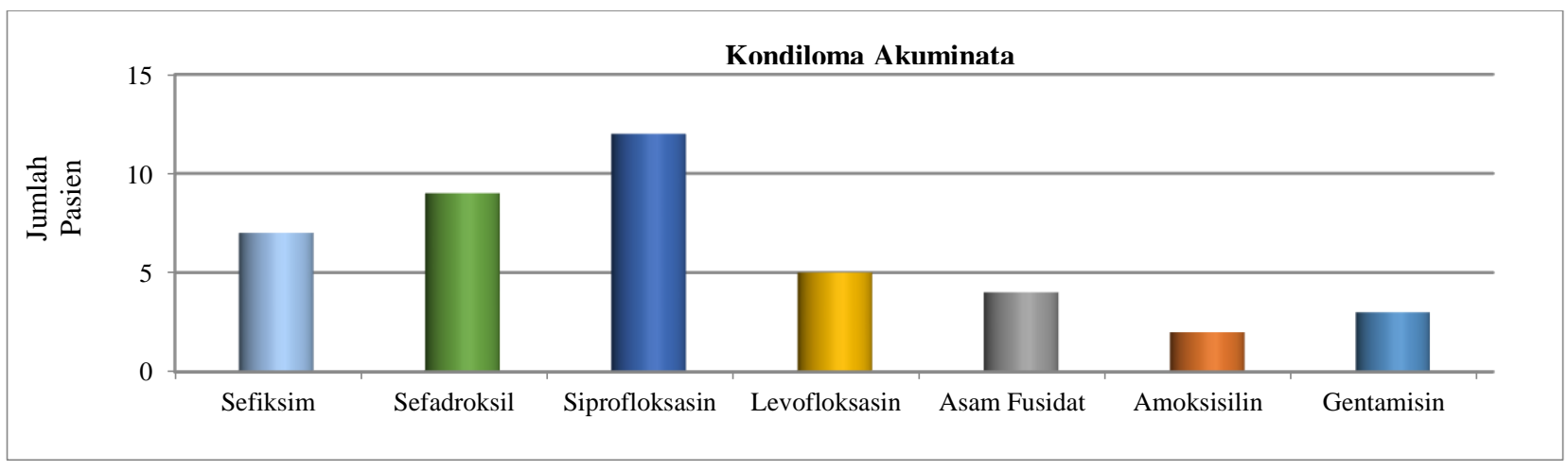

Gambar 9. Diagram Distribusi Pengobatan Pasien Kondiloma akuminata. 
Hasil penelitian menunjukkan bahwa obat yang paling banyak digunakan pasien kondiloma akuminata dengan tindakan elektrokauterisasi adalah antibiotik golongan fluoroquinolon yaitu siprofloksasin dengan persentase sebesar 28,57\%. Siprofloksasin merupakan jenis antibiotik yang paling banyak diberikan pada pasien kondiloma akuminata dengan tindakan elektrokauterisasi. Hal tersebut telah sesuai dengan Permenkes (2011) yang menyebutkan bahwa pemberian antibiotik sebelum, saat dan hingga 24 jam pasca operasi dengan tujuan untuk mencegah terjadi infeksi luka operasi dan penghambatan muncul flora normal resisten.

Mekanisme kerja siprofloksasin adalah dengan cara menghambat DNA gyrase dan topoisomerase IV. Dosis oral yang dibutuhkan untuk dewasa dalam kasus ini yaitu 250-750 mg untuk setiap $12 \mathrm{jam}^{8}$.

\section{d. Pola Pengobatan Herpes genitalis}

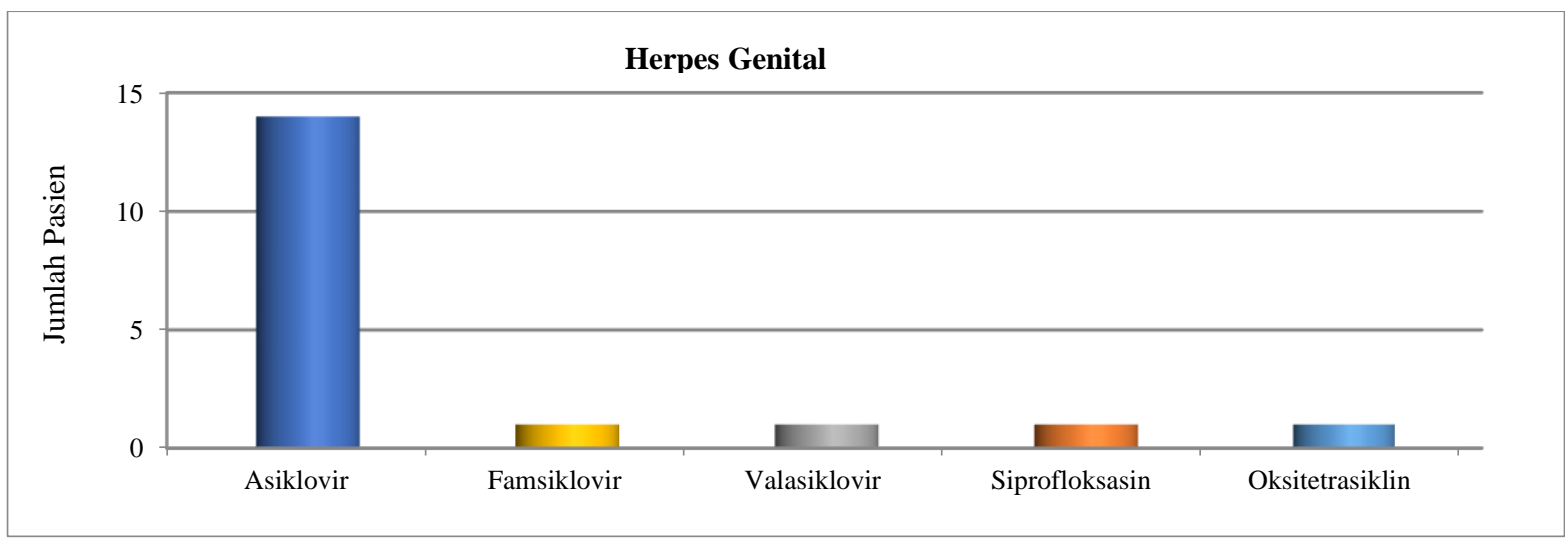

Gambar 10. Diagram Distribusi Pengobatan Pasien Herpes genitalis.

Hasil penelitian menunjukkan bahwa obat yang paling banyak digunakan pasien herpes genitalis adalah antivirus asiklovir dengan persentase sebesar 77,80\%. Asiklovir merupakan obat antivirus yang paling efektif terhadap virus herpes. Dosis untuk herpes genital yakni 5 x sehari $200 \mathrm{mg}$ tablet $^{8}$.

Virus herpes simpleks (HSV), mengandung timidin kinase yang mengubah asiklovir menjadi bentuk monofosfat. Selanjutnya monofosfat mengalami fosforilasi oleh enzim sel pejamu menjadi asikloguanosin trifosfat yang menghambat polimerase DNA virus dan 
sintesis DNA virus ${ }^{7}$.

e. Pola Pengobatan Sifilis

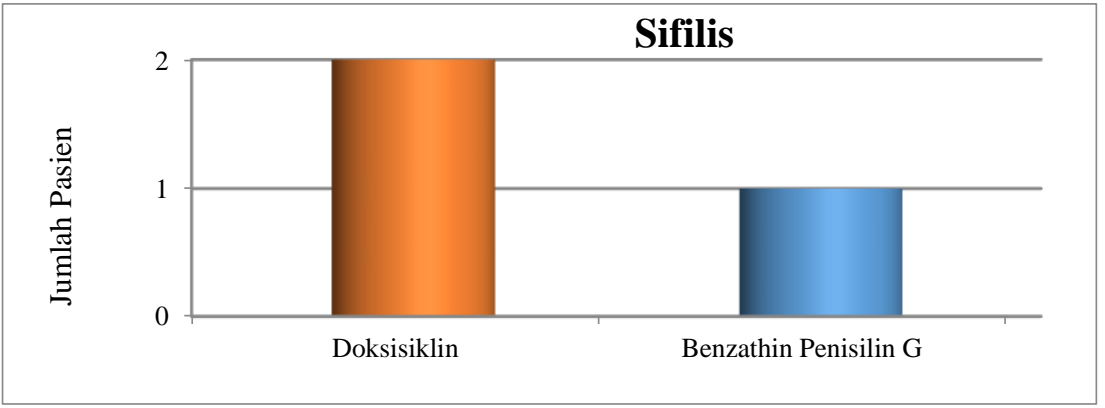

Gambar 11. Diagram Distribusi Pengobatan Pasien Sifilis.

Hasil penelitian menunjukkan bahwa obat yang paling banyak digunakan pasien sifilis adalah antibiotik golongan tetrasiklin yaitu doksisiklin dengan persentase sebesar $66,67 \%$.

Doksisiklin merupakan antibiotik golongan tetrasiklin dan mempunyai spektrum luas. Dosis yang digunakan dalam pengobatan sifilis ialah $200 \mathrm{mg} /$ hari. Mekanisme kerja doksisiklin ialah berikatan secara reversibel dengan subunit ribosom 30s dan mencegah terbentuknya ikatan tRNA-aminoasil pada kompleks mRNA ribosom ${ }^{8}$.

\section{f. Pola Pengobatan Chancroid}

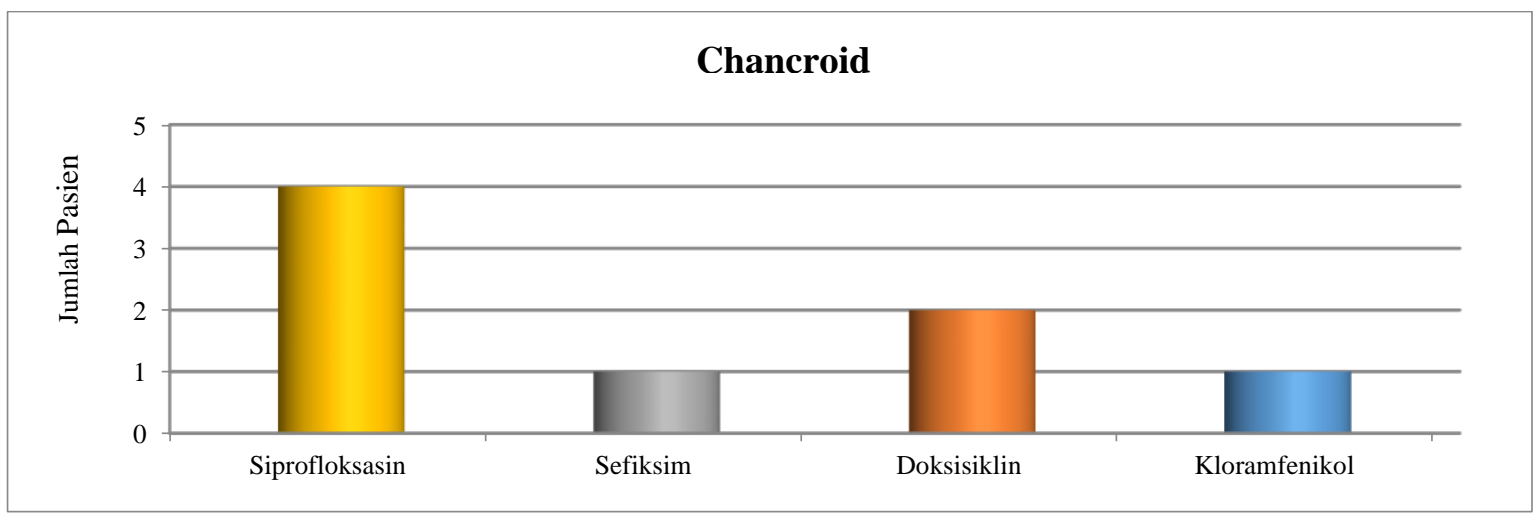

Gambar 12. Diagram Distribusi Pengobatan Pasien Ulkus genital. 
Hasil penelitian menunjukkan bahwa obat yang paling banyak digunakan pasien chancroid adalah antibiotik golongan fluoroquinolon yaitu siprofloksasin dengan persentase sebesar $50 \%$.

Siprofloksasin termasuk antibiotik golongan fluoroquinolon yang berspektrum luas. Dosis siprofloksasin yakni 400-600 mg/hari. Aktivitas siprofloksasin sangat efektif membunuh bakteri penyebab chancroid. Dengan mekanismenya yaitu menghambat replikasi DNA bakteri dengan cara melekatkan molekulnya pada DNA gyrase 9 .

\section{g. Pola Pengobatan Trichomoniasis}

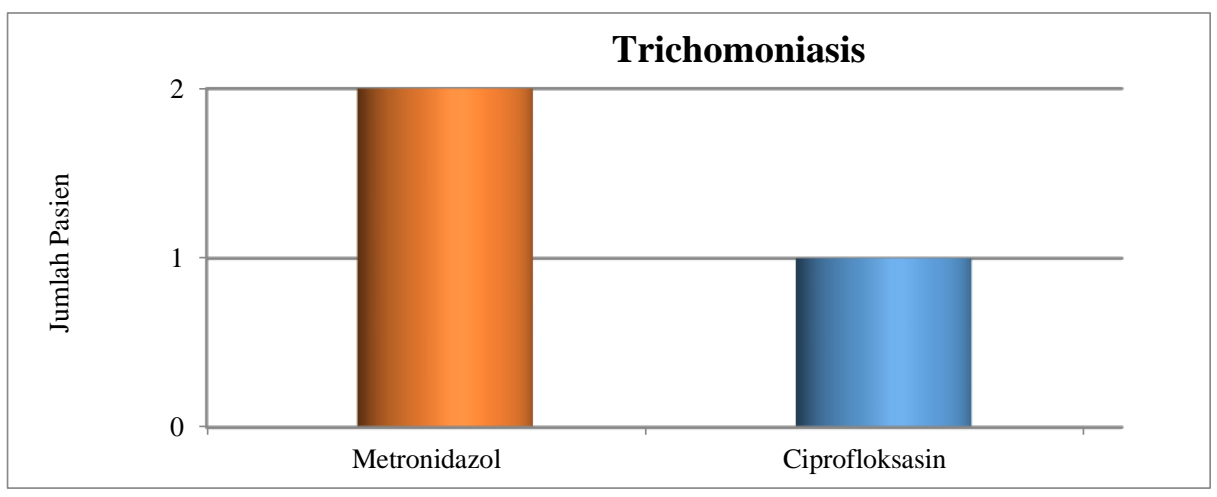

Gambar 13. Diagram Distribusi Pengobatan Pasien Trichomoniasis.

Hasil penelitian menunjukkan bahwa obat yang paling banyak digunakan pasien trichomoniasis adalah antiprotozoa golongan nitro-imidazol yaitu metronidazol dengan persentase sebesar $66,67 \%$.

Metronidazol adalah antimikroba golongan nitro-imidazol dengan aktivitas yang sangat baik terhadap protozoa. Spektrum antiprotozoanya mencakup Trichomonas vaginalis yakni penyebab infeksi trichomoniasis. Mekanisme kerjanya ialah berinteraksi dengan DNA menyebabkan perubahan struktur helik DNA dan putusnya rantai sehingga sintesa protein dihambat dan menyebabkan kematian sel. Dosis yang digunakan dalam pengobatan trichomoniasis ialah 400-500 mg tiap 12 jam selama 7 hari $^{8}$.

\section{KESIMPULAN}

Berdasarkan hasil penelitian kajian karakteristik dan pola pengobatan infeksi menular seksual di RSUD A.W. Sjahranie Samarinda, maka dapat disimpulkan bahwa karakteristik 
pasien infeksi menular terbanyak ialah berjenis kelamin laki-laki yakni sebanyak 55 pasien, sedangkan 53 pasien berjenis kelamin perempuan. Karakteristik pasien laki-laki penderita infeksi menular seksual mayoritas berusia 26-35, tingkat pendidikan SLTA, pekerjaan sebagai karyawan swasta, dan status belum menikah. Sedangkan karakteristik pada pasien perempuan penderita infeksi menular seksual mayoritas berusia 17-25, tingkat pendidikan SLTA, pekerjaan sebagai IRT, dan status menikah. Jenis penyakit infeksi menular seksual terbanyak pada pasien laki-laki ialah Gonorrhea, sedangkan pada pasien perempuan ialah Kondiloma Akuminata. Obat yang paling sering digunakan pada pengobatan Gonorrhea ialah Sefiksim, pada pengobatan Kondiloma Akuminata ialah Ciprofloxacin, pada pengobatan Herpes Genital ialah Asiklovir, pada pengobatan Candidiasis ialah Ketokonazol, pada pengobatan Sifilis ialah Doxicyclin, pada pengobatan Ulkus Genital ialah Ciprofloxacin, dan pada pengobatan Trichomoniasis ialah Metronidazol.

\section{DAFTAR PUSTAKA}

1. Bobak, L. 2005. Keperawatan Maternitas, Edisi 4. EGC : Jakarta.

2. Garcia A.L, Madkan V.K, dan Tyring S.K. 2008. Gonorrhea and Other Venereal Disease. Mc Graw Hill : New York.

3. Habif, Thomas P. 2004. Warts, Herpes Simplex, and Other Viral Infections. Edisi keempat. Mosby : Philadelphia.

4. Kumalasari, I., dan Andhyantoro, I. 2012. Kesehatan Reproduksi untuk Mahasiswa Kebidanan dan Keperawatan. Salemba Medika : Jakarta.

5. Menteri Kesehatan Republik Indonesia. 2011. Pedoman Umum Penggunaan Antibiotik. Kementerian Kesehatan Republik Indonesia : Jakarta.

6. Muda, F.M, Zees R, Monayo E.R. 2014. Faktor - faktor yang Berhubungan dengan Kejadian Infeksi Menular Seksual. Universitas Negeri Gorontalo : Gorontalo.

7. Neal, Michael J. 2006. Farmakologi Medis Edisi Kelima. Erlangga : Jakarta.

8. Sukandar, E.Y., dkk. 2008. ISO Farmakoterapi. ISFI : Jakarta.

9. Triono, Aviv., dan Purwoko, Akhmad Edy. 2012. Efektifitas Antibiotik Golongan Sefalosporin dan Kuinolon. Jurnal Mutiara Medika, 12 (1), 6-11.

10. Zubier, F. 2009. Kondiloma Akuminata. Balai Penerbitan FKUI : Jakarta. 